\title{
Changes in Soil Seed Bank and Vegetation at Abandoned Bait Sites in a Central European Hilly Area ${ }^{\dagger}$
}

\author{
Katalin Rusvai * and Szilárd Czóbel
}

Citation: Rusvai, K.; Czóbel, S. Changes in Soil Seed Bank and Vegetation at Abandoned Bait Sites in a Central European Hilly Area. 2021,

volume number, $\mathrm{x}$.

https://doi.org/10.3390/xxxxx

Academic Editor: name

Published: date

Publisher's Note: MDPI stays neutral with regard to jurisdictional claims in published maps and institutional affiliations.

Copyright: (C) 2021 by the authors. Submitted for possible open access publication under the terms and conditions of the Creative Commons Attribution (CC BY) license (http://creativecommons.org/licenses/by/4.0/).
Department of Nature Conservation and Landscape Ecology, Hungarian University of Agriculture and Life Sciences, H-2100 Páter Károly street 1, Gödöllő, Hungary; Czobel.Szilard@uni-mate.hu

* Correspondence: r.kati24@gmail.com; Tel.: +06-20-331-5891

+ Presented at the 1st International Electronic Conference on Biological Diversity, Ecology and Evolution, 1531 March 2021; Available online: https://bdee2021.sciforum.net/.

\begin{abstract}
Feeding places for shooting wild boar (ie., bait sites) may cause weed infestation in natural habitats. We examined the vegetation and the soil seed banks of three current and three-1, 8 and 10 years old-abandoned baits, using vegetation survey along transects and seedling emergence methods. In case of vegetation, the density and the number of weeds were significantly higher at current baits. In addition, the abundance of weeds decreased with the time of abandonment, but the number of weeds remained similar. Concerning the seed bank, the species number and the total seed density highly varied, but due to the frequent disturbances, they were lower at current baits. Only the proportion of weed species was significantly lower at abandoned sites, the abundancy of weed seeds was similar, and did not decrease in time. Even, the youngest bait showed the lowest, while the oldest one the highest proportion of weed seeds among the abandoned sites. Generally, long-term persistent seeds dominated, except for the oldest site, indicating the lower level of disturbance. Vegetation regenerates relatively quickly, but the seed banks remain infected for years, which can be a potential source of secondary invasions.
\end{abstract}

Keywords: bait site; soil seed bank; abandonment; weed invasion; degradation; regeneration

\section{Introduction}

Feeding wildlife is a very widespread management tool in the world, especially in North America and Central Europe [1]. However, its environmental impacts may be widely diverse [2]. In the main, it is the effects on animal populations that are studied [3], but some researchers have also examined the changes in seedling establishment and regeneration [4]. Only a few publications deal with the herbaceous layer in connection with the effects of wild game feeding [1,5]. In Hungary, supplementary feeding is not so common, because of the increasingly milder winters. However, the use of feeding places for wild boar hunting (at so-called bait sites) is very popular. A bait site is a small clearing established approximately 30 to 50 metres from hunting blinds. In general corn-cobs or seed are scattered on the ground, but other agricultural and food industry by-products (e.g., molasses, fresh and dried beet slices) are used [6]. The legislation is not so strict, thus these sites are often invaded by weeds. Thanks to the poor quality of the forage and the intensive use of it, ruderal and segetal vegetation may became dominant at these sites. Previous studies showed that bait sites can cause significant degradation in natural habitats. Although, the weed infestation typically extends only to the immediate environment of the baits - in general, weed species are present in greater abundance up to eight to ten metres from the centre of the baits - patches of valuable habitat can be destroyed. While, open sites, like forest clearings, are especially vulnerable and represent the most endangered habitats, forest baits have proven to be less open to invasions [7]. What is not yet known, however, is what happens to baits after they are abandoned. As usual, stress- 
tolerant and nitrophilous species indicate the location of former baits, but the regeneration processes are unknown. There are many studies focusing on the succession of old-fields after the cessation of agricultural cultivation e.g., [8,9]. In the case of abandoned bait sites, the high proportion of segetal weeds, the frequent soil disturbances and the high level of anthropogenic impact induce similar conditions to those found in old-fields after abandonment, but the courses of succession may be different. The composition of the soil seed bank is also unknown. The soil seed bank is a major determinant of vegetation dynamics in many plant community types and may play a central role in the recruitment and establishment of species reproducing by seeds [10]. It may also provides a storage effect [11], enabling the coexistence of species with different environmental demands and may improve the capacity of invasive species to establish [12]. What is more, it is well known that weed seeds remain viable in the soil for periods of decades $[13,14]$.

In recent years, thanks to the effects of viruses affecting animals (ASFV; African Swine Fever Virus) and humans (Covid-19; SARS-CoV-2), the extent of hunting has decreased, and thus more and more bait sites are being abandoned. The issue of identifying what changes will occur in the vegetation and in the soil seed bank after abandonment of baits therefore is of growing interest and concern. In the present work, it is assumed that (1) the regeneration of the vegetation will be clearly detectable at abandoned sites, and the extent of weed invasion will decrease with the time of abandonment; (2) the soil seed bank of current baits will characterized by a high proportion of weed seeds, and this will also decrease with time; (3) the proportion of long-term persistent seeds will also indicate the decreasing level of disturbance, and will be the highest at current baits, decreasing with time.

\section{Experiments}

\subsection{Study Site}

The study area is situated in the Mátra Mountains of Hungary. The site under investigation is located in the southern part of the mountain range, in the Turkey oak-sessile oak zone. This habitat characterized by a variable mixture of Turkey oak (Quercus cerris L.) and sessile oak (Quercus petraea (Matt.) Liebl.). In the tree layer shadowing trees are absent or very rare [15]. The site is located in the Mátra Landscape Protection Area. Comprehensive forest and wildlife management is carried out in this protected zone [16].

\subsection{Sampling Setup}

On the basis of preliminary field assessments [7], three current baits in use for several years $(\mathrm{C} 1, \mathrm{C} 2, \mathrm{C} 3)$ were selected and three sites that were abandoned 1,8 and 10 years ago (A1, A2, A3), respectively, using the space-for-time substitution method [17]. All sites are located in clearings classified as mesic hay and dry molinia meadows according to the MÉTA database (the Hungarian acronym for the Landscape Ecological Vegetation Database \& Map of Hungary) [18]. Following the selection, two surveys were conducted in late spring and summer, in May and August 2019. In the course of the surveys, four transects were set out from the centre of the bait sites, each consisting of $221 \times 1 \mathrm{~m}$ tangential quadrats in which a vegetation survey was conducted, with the estimation of percentage cover. The centers of the bait sites were determined by the actual placement of the feed, which was clearly visible in each case. At abandoned sites, the stones, often used at bait sites, were used as a guide to find the center. Considering the extent of the bait sites, 22 sampling units were set in each transects.

The soil seed bank experiment was conducted in May 2019. Soil was sampled in 12 $10 \times 10 \times 5 \mathrm{~cm}$ plots, in the center of the bait sites, randomly located in a circle with a radius of $2 \mathrm{~m}$. Considering that $90 \%$ of the seeds are found the upper $5 \mathrm{~cm}$ of the soil $[19,20]$, the soil was sampled down to this depth. Soil samples were sieved to remove larger fragments, such as stems, roots, and rocks. Then, samples were transferred into plastic trays and conditioned in a greenhouse for 15 months. Emerging seedlings were regularly counted and 
removed. Unidentified seedlings were transplanted and grown till they could be identified.

\subsection{Data Processing}

The seed bank and the vegetation of the current and the abandoned bait sites of various ages were evaluated, based on their species list and abundance (cumulative cover at each sites). To estimate the degree of naturalness of communities, Borhidi's social behaviour types (SBT) classification was used-and this is, in turn, a version of Ellenberg's grouping [21] and Grime's CSR plant functional type system [22] adapted to Pannonian flora. SBTs derive from species' behavior and ecological attributes at a given observation level [23]. In this study two large groups were employed: (1) naturalness indicator species: stress tolerant specialists $-S$; competitors of natural habitats $-C$; stress tolerant generalists-G; natural pioneers-NP; disturbance tolerant plants-DT; (2) degradation indicator/weed species: native weed species $-\mathrm{W}$; introduced crops running wild-I; adventitious weeds $-\mathrm{A}$; ruderal competitors of the natural flora $-\mathrm{RC}$; alien competitors, aggressive invaders $-\mathrm{AC}$. To evaluate the changes in the spatial distribution of weeds, the presence of weed species in the quadrats along the transect was compared using p-tests. To assess the effects of decreasing level of disturbances transient $(\mathrm{T})$, short-term persistent (SP), and long-term persistent (LP) seed bank type classification was used, following Thompson [24].

\section{Results}

\subsection{Vegetation Composition}

At the current bait sites 133 species ( 82 natural, 51 weed) were found, while at abandoned sites, this figure was 161 species (123 natural, 38 weed). The number of aliens was 12 at current baits, 6 at abandoned sites. The cumulative cover $(p=0.0498)$ and the number $(p=0.0084)$ of weeds was significantly higher at current bait sites. The number of natural species was lower at current sites $(p=0.0044)$, but not in cover. However, the proportion of weed species was significantly higher at current sites considering both their density ( $p$ $=0.0376)$ and species number $(p=0.0005)$. When the SBT categories are considered, only the number of ruderal competitor (RC) species proved to be significantly lower at abandoned sites. The cumulative cover of weeds decreased as the time of abandonment inceased (Figure 1a), but the number of weeds remained similar (Figure 1b). The number and the abundance of weeds were higher in all cases in August than in May.

If the spatial distribution of the changes along the transect is examined, significant changes can be mostly detected in the center of the baits (Table 1). The highly significant differences are to be found mainly in the number of the weeds, especially between the youngest and the oldest sites. The cover of weeds differed between the site abandoned for 1 year and the two older sites; and in fact, the latter two proved to be very similar. 


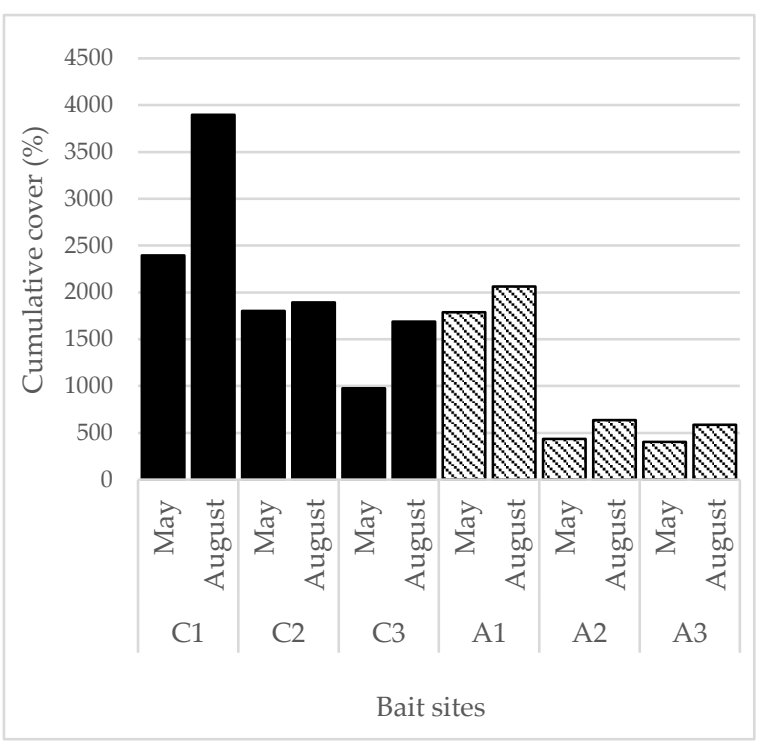

(a)

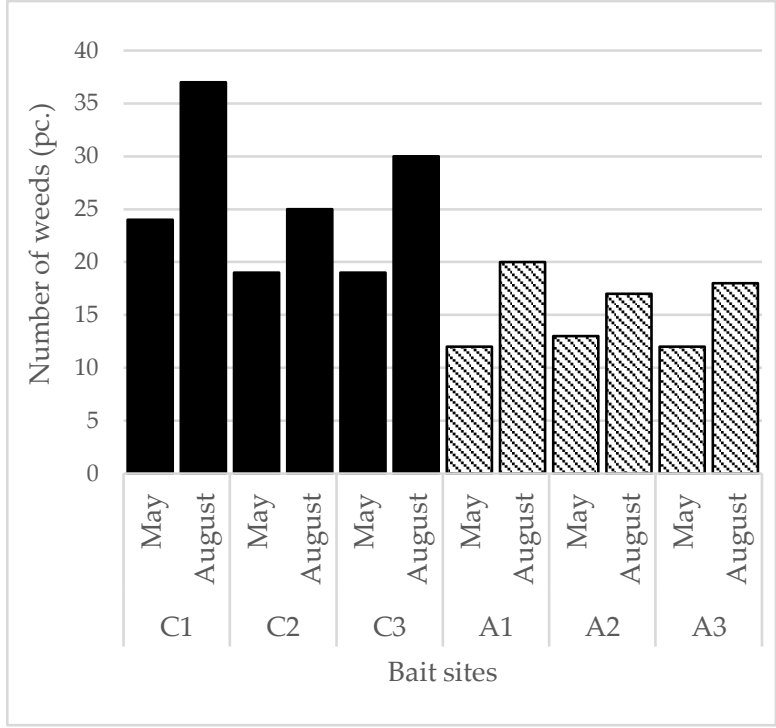

(b)

Figure 1. The abundancy and number of weed species in the vegetation of the current and the abandoned baits, (a) The abundancy of weeds according to the cumulative cover of all weed species in the 88 quadrats at each bait sites; (b) The number of weed species at each bait sites. C1, C2, C3-current bait sites; and abandoned bait sites: A1-abandoned for 1 year, A2-abandoned for 8 years, A3-abandoned for 10 years.

Table 1. Significant differences between the bait sites abandoned for different lenghts of time along the transects (in 1-22 quadrats) according to the cover and the number of weed species.

\begin{tabular}{|c|c|c|c|c|c|c|c|c|c|c|c|c|c|c|c|c|c|c|c|c|c|c|}
\hline \multicolumn{23}{|c|}{ Cover of Weeds } \\
\hline & 1 & 2 & 3 & 4 & 5 & 6 & 7 & 8 & 9 & 10 & 11 & 12 & 13 & 14 & 15 & 16 & 17 & 18 & 19 & 20 & 21 & 22 \\
\hline A1-A3 & $*$ & $* *$ & & & & & $* *$ & & & & * & * & & & & & & & & & & \\
\hline $\mathrm{A} 1-\mathrm{A} 2$ & $*$ & $* *$ & $*$ & * & $*$ & & $*$ & & & & & & & & & & & & & & & \\
\hline $\mathrm{A} 2-\mathrm{A} 3$ & & * & & & & & & & & & & & & & & & & & & & & \\
\hline \multicolumn{23}{|c|}{ Number of Weeds } \\
\hline & 1 & 2 & 3 & 4 & 5 & 6 & 7 & 8 & 9 & 10 & 11 & 12 & 13 & 14 & 15 & 16 & 17 & 18 & 19 & 20 & 21 & 22 \\
\hline $\mathrm{A} 1-\mathrm{A} 3$ & ** & *** & $* *$ & ** & $*$ & & * & & & & $* * *$ & $* * *$ & * & & & & & & & & & \\
\hline $\mathrm{A} 1-\mathrm{A} 2$ & & $* *$ & & & & & & & & & & * & & & & & & & & & & \\
\hline A2-A3 & & $* * *$ & & $* *$ & & & & & & & & & & & & & & & & & & \\
\hline
\end{tabular}

A1: bait abandoned for 1 year; A2: bait abandoned for 8 years; A3: bait abandoned for 10 years. ${ }^{* * *}$ : highly significant $(p<$ $0.001){ }^{* *}$ : moderately significant $(p<0.01){ }^{*}$ : poorly significant $(p<0.05)$.

\subsection{Soil Seed Bank Composition}

At current bait sites 46 species were found, 19 natural (41.3\%) and 27 weed (58.7\%) species, while at abandoned sites 58 species were detected, of which 36 were natural $(62.1 \%)$ and 22 weed (37.9\%) species. The number of aliens was 11 at current baits, and 6 at abandoned sites. The species number and also the total seed density proved to be very variable, but in general they were lower at current baits (Figure 2). Only the proportion of weed species was significantly lower at abandoned sites $(p=0.0003)$, while the abundancy of weed seeds was similar to or sometimes even higher than, at current baits. The abundance of weed seeds did not decrease with the time; indeed, among the abandoned sites, the most recently abandoned bait had the lowest proportion of weed seeds, and the oldest had the highest (Figure 2a). The number of weed species was also the highest at the oldest abandoned bait (Figure $2 b$ ), while the proportion of weeds remained very similar between the abandoned baits of different ages (42.9\%, $44.1 \%$ and $42.1 \%)$. 


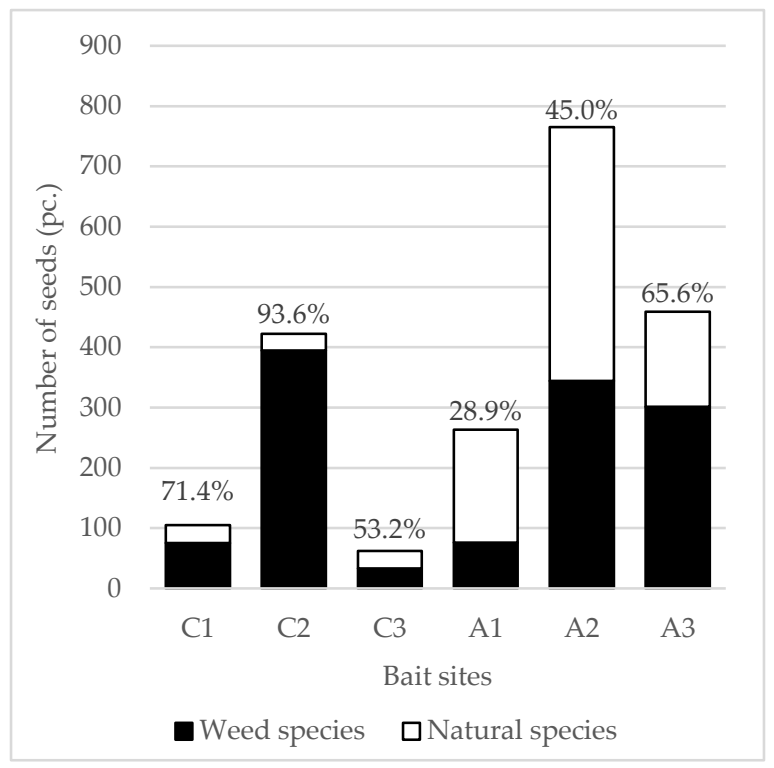

(a)

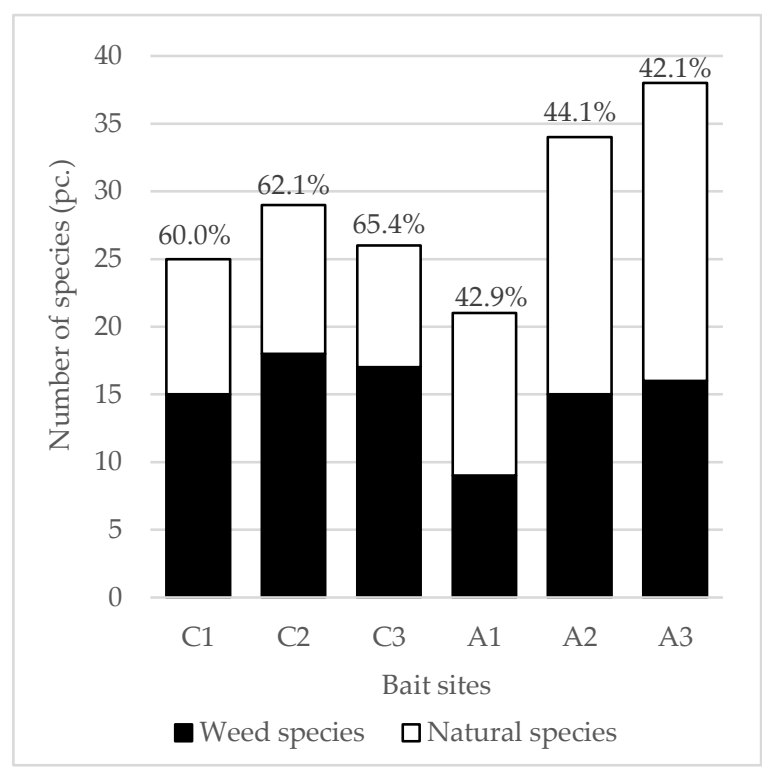

(b)

Figure 2. Seed density and the number of species in the soil seed bank experiment, with the values of weed proportion, (a) The number of weed and natural species seeds in the soil seed bank and the proportion of weeds; (b) The number of weed and natural species in the soil seed banks and the proportion of weeds. C1, C2, C3-current bait sites; and abandoned bait sites: A1-abandoned for 1 year, A2-abandoned for 8 years, A3-abandoned for 10 years.

\subsection{Seed Bank Persistence}

Long-term persistent seeds dominated in all cases. At current bait sites, the number and the proportion of long-term persistent species varied between 65.5 and 96.2\%. At abandoned sites it remained quite high (with the maximum value of $94.7 \%$ at the site abandoned for 1 year), but decreases considerably with the time (Figure 3). At the same time, the proportion of transient and short-term persistent species and their seed density also increased. This is especially noticeable at the oldest abandoned site (A3), where the proportion of seeds according to their longevity, changed radically. 


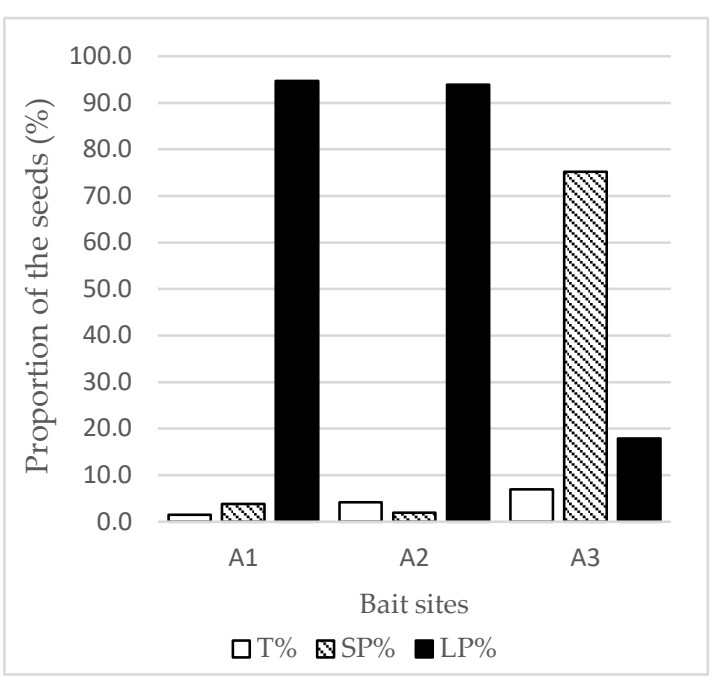

(a)

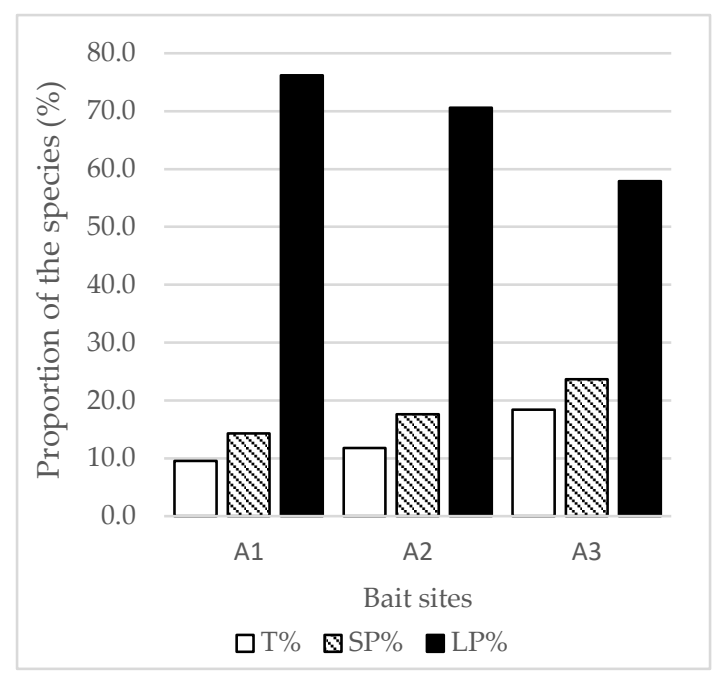

(b)

Figure 3. The proportion of transient (T), short-term persistent (SP) and long-term persistent (LP) seeds and species at abandoned sites, (a) The proportion of the seeds; (b) The proportion of the species. A1: bait abandoned for 1 year; A2: bait abandoned for 8 years; A3: bait abandoned for 10 years.

\section{Discussion}

\subsection{Vegetation Composition}

The density and the number of weed species proved to be significantly higher at current baits. As expected, the cover of weeds decreased with the time of abandonment. Significant differences became apparent, especially insofar as the centre of the baits are concerned, mainly between the most recent and the two oldest sites. The number of weed species, however, did not display any decrease; it was similar at all abandoned sites. As similar result was obtained by Csecserits et al. (2007) [25] in the examination of the secondary succession of abandoned sandy agricultural fields in Hungary. That research also found a decrease in the abundance of species that require some degree of disturbance to establish, but the number of such species did not change in the course of the 5 years studied. Generelly, segetal weeds are suppressed by natural species, but some individuals remain present for a long time. Similar changes may well have happened at abandoned bait sites. As the addition of contaminated forage ceased, the artificial weed seed fluxes also ended. Presumably, it was this that caused the significant decrease in the number of ruderal competitor (RC) species, and also caused the slight decrease in the number of weed species, as well. Some species, however, may still be present because of the gaps caused by animals, which often return to these sites for a long time after abandonment. These disturbances may promote the germination of remained weeds [26]. In addition, the soil nutrient enrichment caused by the accumulated forage also create conditions favorable to these species [27].

\subsection{Soil Seed Bank Composition}

The soil seed bank proved to be very variable and highly infected after several years. Significant differences between the current and the abandoned bait sites could not be demonstrated, only that the proportion of weed species was significantly lower at the abandoned sites. The reason for this could be the fact that seed banks are generally less likely to change rapidly and support more species than the aboveground vegetation in invaded communities $[28,29]$. Contary to the assumptions made in the early stages of this work, neither the number and the proportion of weed species nor the number and proportion of their seeds decreased with the time of abandonment. What is more, the greatest 
number of weed seeds was detected at the two sites abandoned for the longest times, and the proportion of weed seed was in fact highest at the oldest site. However, it should be noted, that the 1 year-old bait is a wetter habitat, and thus promotes the germination of the species of the local community. It was not possible to demonstrate any increase in species number and seed density with the increasing level of disturbance, in contrast to other studies [30,31]. The lowest values were found at current bait sites. The reason may be the severe and frequent disturbances, which are concentrated in a relatively small area, and are therefore more severe than those caused by grazing, and which are the focus of most of the other published studies [32,33]. One reason may be the large amount of accumulated litter (a mixture of the residual forage) can act as a trap for propagules, thus it prevent seeds from reaching the soil [34]. Litter can also change physical conditions such as soil temperature and moisture [35], and release allelochemicals, which may be toxic [36], diminishing the amount of viable seeds. What is more, it is proved that at the local scale ground-foraging animals can strongly influence seed availability and the arrival of seeds into regeneration safe sites [37]. The high level of animal and human trampling results in a high degree of soil compaction. This, in turn, may lead to decreased oxygen availability in soil and allow the build up of toxic gases, all of which can reduce the chances of seed survival [38].

\subsection{Seed Bank Persistence}

The seed bank theory, according to which the proportion of persistent species increases with disturbance $[39,40]$, did, however, prove to be true. The number and seed density of species with a persistent seed bank decreases with the time of abandonment. This may well be related to the decrease in human and animal disturbances, thus displaying a similarity to the changes frequently detected along grazing gradients $[32,33]$.

\section{Conclusions}

Vegetation proved capable of regenerating relatively quickly. Several studies have shown that the regeneration of abandoned fields is relatively good in Eastern Europe. Similarly, rapid secondary succession was found by Jongepierova et al. (2004) [41] in the Czech Republic, by Ruprecht (2006) [42] in the case of Romanian abandoned fields, and by Csecserits et al. (2007) [25] in Hungary. These results are most likely due to the presence of semi-natural grassland patches in the surroundings that serve as propagule sources. In the case of abandoned bait sites, these sources may be taken as given, because the degradation concerns relatively restricted areas in a matrix of extensive natural habitats. Despite this, complete regeneration will take several years. Also, in the Mátra Mountains a study was conducted, which found that old fields truly returned to resembling natural habitats only 50-110 years after abandonment [43]. Thus, the process of the extinction of weeds will last for many years. While weed cover may well decreases relatively quickly on the ground, weed seeds in the soil seed bank may remain viable for decades. In this way, the presence of invading weeds may facilitate invasion by other species, and according to the 'invasional meltdown hypothesis' [44], the result may be secondary invasions; many studies have demonstrated this [45].

In practical terms, the chronosequence approach was chosen instead of monitoring, so mainly because of the different environmental conditions and land-use histories, the predictions may not be so reliable. However, the goal was to identify the prevalent courses of succession at abandoned bait sites. As Csecserits et al. (2007) [25] also concluded, the space-for-time substitution method does seem to be effective, as it shows the general trends of successional changes and describes processes that have already occurred; nature conservation interventions can therefore rely on the results obtained from it. Further research is nevertheless needed. Monitoring over the course of a number of years may have revealed the interannual changes, as well, and it may have been possible to detect the 
effect of other factors such as differences in land-use history and environmental conditions.

Author Contributions: K.R. conceived, designed and performed the experiments; K.R. and S.C. analyzed the data; S.C. contributed analysis tools; K.R. wrote the paper. All authors have read and agreed to the published version of the manuscript.

\section{Institutional Review Board Statement:}

Informed Consent Statement:

Data Availability Statement:

Acknowledgments: We are grateful to Paul Thatcher for English proofreading.

Conflicts of Interest: The authors declare no conflict of interest.

\section{References}

1. Arnold, J.M.; Gerhardt, P.; Steyaert, S.M.J.G.; Hochbichler, E.; Hacklander, K. Diversionary feeding can reduce red deer habitat selection pressure on vulnerable forest stands, but is not a panacea for red deer damage. For. Ecol. Manag. 2018, 407, 166-173, doi:10.1016/j.foreco.2017.10.050.

2. Selva, N.; Berezowska-Cnota, T.; Elguero-Claramunt, I. Unforeseen Effects of Supplementary Feeding: Ungulate Baiting Sites as Hotspots for Ground-Nest Predation. PLoS ONE 2014, 9, e90740, doi:10.1371/journal.pone.0090740.

3. Milner, J.M.; Van Beest, F.M.; Schmidt, K.T.; Brook, R.K.; Storaas, T. To feed or not to feed? Evidence of the intended and unintended effects of feeding wild ungulates. J. Wildl. Manage. 2014, 78, 1322-1334, doi:10.1002/jwmg.798.

4. Mathisen, K.M.; Rèmy, A.; Skarpe, C. Shoot growth responses at supplementary feeding stations for moose in Norway. Alces 2015, 51, 123-133.

5. Rinella, M.J.; Dean, R.; Vavra, M.; Parks, C.G. Vegetation responses to supplemental winter feeding of elk in western Wyoming. West. N. Am. Nat. 2012, 72, 78-83, doi:10.3398/064.072.0109.

6. Heltai, M.; Sonkoly, K. The role and opportunities of feeding in game management (Review). AWETH 2009, 5, 1-22.

7. Rusvai, K.; Kispál, L.; Czóbel, Sz. Assessment of weed invasion at bait sites in the Mátra Landscape Protection Area. Columella J. Agric. Environ. Sci. 2019, 6, 37-44, doi:10.18380/SZIE.COLUM.2019.6.2.37.

8. Csecserits, A.; Czúcz, B.; Halassy, M.; Kröel-Dulay, G.; Rédei, T.; Szabó, R.; Szitár, K.; Török, K. Regeneration of sandy old-fields in the forest steppe region of Hungary. Plant Biosyst. 2011, 145, 715-729, doi:10.1080/11263504.2011.601340.

9. Boecker, D.; Centeri, C.; Welp, G.; Möseler, B.M. Parallels of secondary grassland succession and soil regeneration in a chronosequence of central-Hungarian old fields. Folia Geobot. 2015, 50, 91-106, doi:10.1007/s12224-015-9210-3.

10. Thompson, K.; Grime, P.J. Seasonal variation in seed banks of herbaceous species in ten contrasting habitats. J. Ecol. 1979, 67, 893-921.

11. Chesson, P.L. The storage effect in stochastic population models. Lect. Notes Biomath. 1984, 54, 76-89.

12. Gioria, M.; Pyšek, P.; Moravcová, L. Soil seed banks in plant invasions: Promoting species invasiveness and long-term impact on plant community dynamics. Preslia 2012, 84, 327-350.

13. Lewis, J. Longevity of crop and weed seeds: Survival after 20 years in soil. Weed Res. 1973, 13, 179-191, doi:10.1111/j.13653180.1973.tb01262.x.

14. Telewski, F.W.; Zeevaart, J.A.D. 120-yr period from Dr. Beal's seed viability experiment. Am. J. Bot. 2002, 89, 1285-1288.

15. Bölöni, J.; Molnár, Z.; Biró, M.; Horváth, F. Distribution of the (semi-) natural habitats in Hungary II. Woodlands and shrublands. Acta Bot. Hung. 2008, 50, 107-148, doi:10.1556/ABot.50.2008.Suppl.6.

16. Katona, K.; Kiss, M.; Bleier, N.; Székely, J.; Nyeste, M.; Kovács, V.; Terhes, A.; Fodor, Á.; Olajos, T.; Rasztovics, E.; Szemethy, L. Ungulate browsing shapes climate change impacts on forest biodiversity in Hungary. Biodivers. Conserv. 2013, 22, 1167-1180, doi:10.1007/s10531-013-0490-8.

17. Pickett, S.T.A. Space-for-time substitution as an alternative to long-term studies. In Long-Term Studies; Likens, G.E., Eds.; Ecology: Approaches and Alternatives; Springer: New York, NY, USA; Berlin, Germany, 1989; pp. 110-135.

18. Available online: https://www.novenyzetiterkep.hu/english/node/1090 (accessed on).

19. Koncz, G.; Papp, M.; Török, P.; Kotroczó, Zs.; Krakomperger, Zs.; Matus, G.; Tóthmérész, B. The role of seed bank in the dynamics of understorey in an oak forest in Hungary. Acta Biol. Hung. 2010, 61, 129-139.

20. Jacquemyn, H.; Van Mechelen, C.; Brys, R.; Honnay, O. Management effects on the vegetation and soil seed bank of calcareous grasslands: An 11-year experiment. Biol. Conserv. 2011, 144, 416-422.

21. Ellenberg, H. Zeigerwerte der Gefäßpflanzen Mitteleuropas. (Indicator values of vascular plants in Central Europe.) Scr. Geobot. 1974, 9, 1-97.

22. Grime, J.P. Plant Strategies and Vegetation Processes; Wiley: Chichester, UK; New York, NY, USA, $1979 ;$ p. 222.

23. Borhidi, A. Social behavior types, the naturalness and relative ecological indicator values of the higher plants in the Hungarian Flora. Acta Bot. Hung. 1995, 39, 97-181. 
24. Thompson, K.; Bakker, J.P.; Bekker, R.M. The Soil Seed Banks of North West Europe: Methodology, Density and Longevity; Cambridge University Press: Cambridge, UK, 1997.

25. Csecserits, A.; Szabó, R.; Halassy, M.; Rédei, T. Testing the validity of successional predictions on an old-field chronosequence in Hungary. Community Ecol. 2007, 8, 195-207.

26. Kotanen, P.M. Effects of gap area and shape on recoloniza-tion by grassland plants with differing reproductive strategies. Can. J. Bot. 1997, 75, 352-361.

27. Bidwell, S.; Attiwill, P.M.; Adams, M.A. Nitrogen availability and weed invasion in a remnant native woodland in urban Melbourne. Austral Ecol. 2006, 31, 262-270, doi:10.1111/j.1442-9993.2006.01575.x.

28. Robertson, S.G.; Hickman, K.R. Aboveground plant community and seed bank composition along an invasion gradient. Plant Ecol. 2012, 213, 1461-1475.

29. Gooden, B.; French, K. Impacts of alien grass invasion in coastal seed banks vary amongst native growth forms and dispersal strategies. Biol. Conserv. 2014, 171, 14-26.

30. Hopfensperger, K.N. A review of similarity between seed bank and standing vegetation across ecosystems. Oikos 2007, 116, 1438-1448, doi:10.1111/j.2007.0030-1299.15818.x.

31. Bossuyt, B.; Honnay, O. Can the seed bank be used for ecological restoration? An overview of seed bank characteristics in European communities. J. Veg. Sci. 2008, 19, 875-884, doi:10.3170/2008-8-18462.

32. Matus, G.; Papp, M.; Tothmeresz, B. Impact of management on vegetationdynamics and seed bank formation of inland dune grassland in Hungary. Flora 2005, 200, 296-306.

33. Ma, M.; Zhou, X.; Du, G. Role of soil seed bank along a disturbance gradient in an alpine meadow on the Tibet plateau. Flora 2010, 205, 128-134., doi:10.1016/j.flora.2009.02.006.

34. Donath, T.W.; Eckstein, R.L. Effects of bryophytes and grass litter on seedling emergence vary by vertical seed position and seed size. Plant Ecol. 2010, 207, 257-268.

35. Holmgren, M.; Scheffer, M.; Huston, M.A. The interplay of facilitation and competition in plant communities. Ecology 1997, 78, 1966-1975.

36. Ruprecht, E.; Józsa, J.; Ölvedi, T.B.; Simon, J. Differential effects of several "litter" types on the germination of dry grassland species. J. Veg. Sci. 2010, 21, 1069-1081.

37. Arruda, A.J.; Costa, F.V.; Guerra, T.J.; Junqueira, P.A.; Dayrell, R.L.; Messeder, J.V.; Rodrigues, A.T.S.; Buisson, E.; Silveira, F.A.O. Topsoil disturbance reshapes diaspore interactions with ground-foraging animals in a megadiverse grassland. J. Veg. Sci. 2020, 31, 1039-1052, doi:10.1111/jvs.12866.

38. Fenner, M.; Thompson, K. The Ecology of Seeds, 2nd ed.; Cambridge University Press: Cambridge, UK, 2005.

39. Thompson, K. The functional ecology of seed banks. In Seed Ecology; Fenner, M., Ed.; Chapman \& Hall: London, UK, 1985; pp. 231-258.

40. Kiss, R.; Valkó, O.; Tóthmérész, B.; Török, P. Seed bank research in Central-European grassland. An overview In Seed Banks: Types, Roles and Research; Murphy, J., Ed.; Nova Science Publishers: New York, NY, USA, 2016; pp. 1-34.

41. Jongepierová, I.; Jongepier, J.W.; Klimeš, L. Restoring grassland on arable land: An example of a fast spontaneous succession without weed-dominated stages. Preslia 2004, 76, 361-369.

42. Ruprecht, E. Successfully recovered grassland: A promising example from Romanian old-fields. Restor. Ecol. 2006, 14, 473-480.

43. Molnár, Z. Sár-hegy (D-Mátra-Mátraalja). In The XI. MÉTA-TÚRA Tour Guid Booklet-Manuscript; Bartha, S., Ed.; MTA ÖBKI: Hungary, Vácrátót, 2008; pp. 34-42. Available online: https://www.novenyzetiterkep.hu/sites/novenyzetiterkep.hu/files/MT11_Bartha_Molnar_2008_A_XI_META_TURA_Fuzet.pdf (accessed on 16 February 2021). (In Hungarian)

44. Simberloff, D.; Von Holle, B. Positive interactions of nonindigenous species: Invasional meltdown? Biol. Invasions 1999, 1, 2132.

45. Jeschke, J.M.; Aparicio, L.G., Haider, S.; Heger, T.; Lortie, C.J.; Pyšek, P.; Strayer, D.L. Support for major hypotheses in invasion biology is uneven and declining. NeoBiota 2012, 14, 1-20, doi:10.3897/neobiota.14.3435. 